\title{
Prevention and protection technologies - How do the growers get ready for climate change?
}

\author{
Nagyné, D.D. ${ }^{1}$, Szabó, Z. ${ }^{2}$, Nyéki, J. ${ }^{2} \&$ Soltész, M. ${ }^{3}$ \\ ${ }^{1}$ Institute of Environmental Sciences, Faculty of Natural Resources Management and Rural Development, \\ Károly Róbert College, Mátrai str. 36. Gyöngyös, H-3200, Hungary demeterd@ karolyrobert.hu \\ ${ }^{2}$ Institute for Research and Development, Centre of Agricultural and Applied Economic Sciences, \\ University of Debrecen, Debrecen, Hungary \\ ${ }^{3}$ College of Kecskemét, Faculty of Horticulture, H-6000 Kecskemét, Erdei Ferenc square 1-3.
}

\begin{abstract}
Summary: Within the sector of fruit growing, climate change related tasks cover a rather wide range of activities. According to what is claimed by the literature, all decisions impacting the sector should be made conformably with climate change in order to advance an increase in yield security. This, regardless of the impacts of climate change, is also one of the key questions in fruit growing. Regarding protection against extreme weather events, in addition to technological and technical elements, the level of importance assumed by farmers for the abovementioned protection techniques as well as the type and extent they intend to use of this in practice are also worth of studying. This ongoing research beginning in 2009 mainly focuses on studying the opinions of fruit farmers making up the target group for this analysis. The questionnaire survey primarily intends to study their knowledge on the definition of climate change as reactivity to unfavourable weather events occurring in the growing. The study aims at providing a realistic view on the fruit-farmers' knowledge on climate change and on how technological elements, new technical solutions applicable to mitigate damage are used during production.
\end{abstract}

Key words: climate change, fruitgrowing, protection, yield security

\section{Introduction}

Although the notion of climate change is familiar to almost everyone, the very meaning of this definition is known and conceived by significantly less. As extreme weather phenomena determine yield security, this fact is extremely important among those directly involved in food production. Based on the experiences obtained so far, fructiculture in Hungary will not be basically impacted by the increase of temperature but the frequency of extreme weather events. Their frequency of occurrence will decisively influence the quantity and quality of fruits growable as well as will result in the shrinking of production areas [Soltész et al., 2007]. Due to scientific uncertainties, it is complicated to analyze the potential impacts of global climate change. And this is also the case as from the empirical results of social scientific studies, only the nature of relations various social groups have today to nature, physical environmental problems and the (mainly believed) impacts of the global climate change can be concluded. Taken society as a whole, exploring future interests is not only difficult as people are aware they should abandon their interests of today for their future interests but also as this future interest is rather difficult to enforce [Szirmai, 2009]. Farmers involved in fructiculture, on the contrary to this general phenomenon, perceive that the implementation of this 'future interest' will determine yield security and by this, their profitableness as during production, they closely apprehend the negative impacts of extreme weather phenomena.

\section{Methods}

In this study, a questionnaire survey frequently applied in social scientific research was used. This method bears a number of advantages as being relatively rapid, suitable for providing descriptive statistical studies on large assemblies and from the data obtained from the results of such surveys, secondary analyses can be simply conducted. Secondary analyses were carried out following simple statistical studies evaluating and quantifying the basic features of the study sample. The descriptive statistical method applied was frequency test during which the variables' relative and cumulative distributions within a given topic were analysed and represented. For multiple answers, the analysis was conducted by applying frequency and crosstabs in accordance with the previously defined groups and sets of multiple answers.

Association between variables of nominal in type advancing our study of hypothesis was described by association measures. During the analysis, data were arranged to crosstabs, validity of causality associations 
assumed based on the arrangement of frequencies were proven by applying definitely a chi-square test. The level of significance was set on the conventional value ( $\leq \leq 0.05)$. This study primarily intends to examine knowledge on the concept of climate change and reactivity to unfavourable weather phenomena occurring in nature among farmers. In addition to these, the research also aimed at obtaining qualitative and quantitative information required for the development of consultancy and research guidelines.

As the character of this study approaches social scientific research, it contains a number of uncertainty factors. Despite these, such a survey on opinions is necessary and relevant as respondents are not only actors of the society as a whole but in the meantime are also active 'participants' in agricultural production otherwise generating a significant level of environmental loading (obviously, global climate change is not only impacted by production itself but also by many other social mechanisms). They are polluters as well as the victims of the pollution and, moreover their exposition in relation to this global environmental problem is rather high.

Risk factors of climate change such as long arid periods, floods, storms, forest fires, discrepancies in drinking water supply, descent of ground water level, spreading of invasive weeds and dragged-in insects, a Mediterranean type conversion of living world, heat stress, allergies, haemal affections and increasing energy demand have become more and more obvious in recent years [Harnos-Csete, 2008]. Such are the risk factors that members of the study's target group face probably the most frequently as well as for them, the occurrence of extreme weather phenomena represents a failure of the rather significant profit for them and even in many cases determining their sustenance (nearly all in the past 5 years frost in May occurred with the one in 2007 being especially crucial with the case being similar for drought damaging plantations on several occasions with the exception only being the past year.).

In the study's first period, 70 farmers were involved in the survey. The answers received were indicative and informative however proved to be inadequate to make final conclusions. The questionnaire, in addition to calibrating questions, intended to survey the knowledge of farmers in relation to the topics below:

- surveying the climate change related knowledge, knowledge on protection and prevention and conditions for application (financial, professional)

- sources of information, type of information (meteorological data required for protection, new protection technological elements, techniques of protection, technological solutions advancing damage mitigation)

- frequency and type of damage (exposition), possibilities for damage mitigation (types of funding, rate of own contribution)

\section{Exposition to climate change}

This study gives a review on the responses received on topics regarding the concept of climate change and the frequency of damage occurrences as well as to the direct exposition of farmers to the negative impacts of climate change.

All respondents had heard about climate change, however had various views on the definition itself (Figure 1). Based on the answers, it is indicated that climate change was associated with extreme weather events having the most intensive direct influence on them or, to be more precise, on production. Regarding damage impacting them, drought and

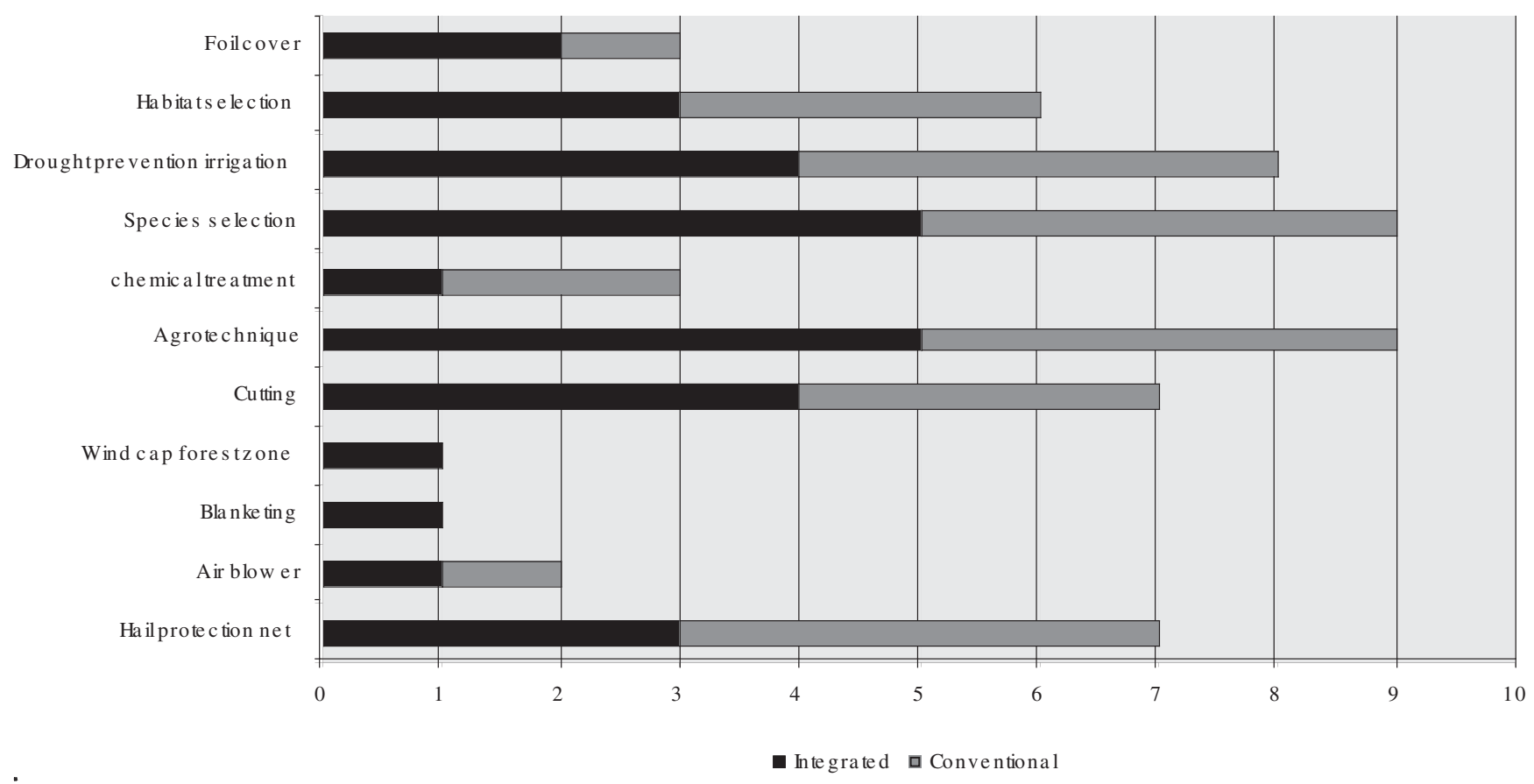

Figure 2. The share of protection technologies applied for preventing damage for various methods of cultivation, in function (\%) of the valid answers, 2010 $\mathrm{p}=0.000, \mathrm{p} \leq 0.05$

Source: On the basis of empirical research self-edited. 


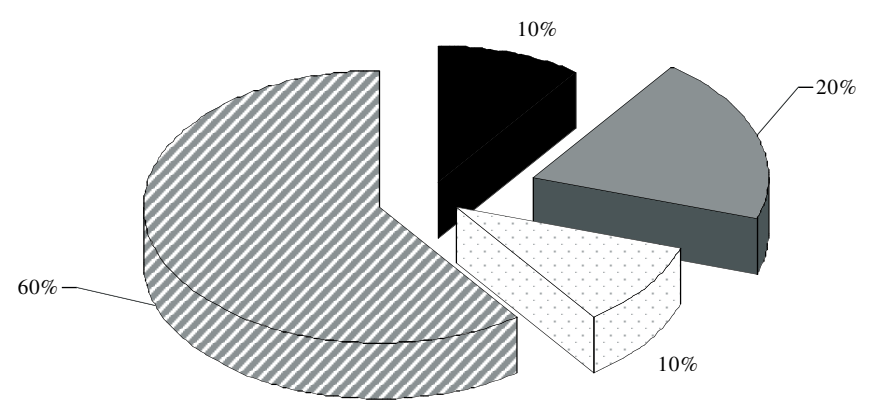

- Delayed endings of seasons

$\square$ Increase of temperature

$\square$ Insufficient precipitation

Extreme weather event

Figure 1.'In your opinion, what does climate change mean?' $\mathrm{p}=0.000, \mathrm{p} \leq 0.05$

Source: On the basis of empirical research self-edited.

sunscald was mentioned the most frequently. This can be originated by the fact that the majority of respondents are hit by both drought and sunscald at several occasions each year. Hail-storm is experienced once in every 2 or 3 years whereas wind damage and storm damage occur less frequently than 23 years. This is likely to be the reason why such are mentioned less frequently when questioned about damage, however it is an important finding that all respondents were hit by some kind of damage in the past 5 years. Their exposition thus in climate change defined and experienced by them as a series of extreme weather events is rather high.

Regarding the technique of protection, in addition to the distribution of the given possibilities, the frequency each category mentioned is also worth of studying (Figure 2). Here, conventional technological elements gained predominance in both categories of cultivation. (70 percent of the respondents pursue integrated farming whereas $30 \%$ applies conventional technologies. At present, no bio-farms are included in the sample.). The share of fruit species can be relevant at correlation tests at present however, taking the relatively low number of samples and the fact that this research is still being carried out this question was not analysed.

Results can greatly contribute to the elaboration of climate change related adaptation technologies for the sector as well as foresee the success of implementation in practice. The results of this survey can primarily advance a more active contribution of farmers regarding the prevention and mitigation of production damages occurring in relation to the climate change. To this, processing of the entire questionnaire following the closure of research and explaining certain sections proved to be problematic and controversial. The way and type of source of information having obtained fruit farmers become capable of mitigating and preventing the above mentioned weather-caused damages can also be a subject to further studies.

The study was carried out funded by NFÜ TECH_08A4/2-2008-0138 and NFÜ TECH_08-A3/2-20080373 grants.

\section{References}

Soltész, M., Nyéki, J. \& Szabó, Z. (2007): Klímaváltozáshoz alkalmazkodó hazai kertgazdaság. (In: A globális klímaváltozás: hazai hatások és válaszok.) Budapest, Szaktudás Kiadó Ház.

Szirmai, V. (2009): Az éghajlatváltozás lehetséges térbeli társadalmi hatásai, a magyar társadalom klímatudatossága, sérülékenysége, alkalmazkodása. http://www.nfft.hu/dynamic/Az eghajlatvaltozas tarsadalmi hatasai klimatudatossag.pdf

Harnos, Zs. \& Csete, L. (2008): Klímaváltozás: környezet - kockázat - társadalom. Budapest: Szaktudás Kiadó Ház. 